FINAL TECHNICAL REPORT

\title{
CSDP: The Seismology of Continental Thermal Regimes
}

DOE Contract DE-AC-02-76-ER-02534

January 1, 1975 - December 31, 1984

Keiiti Aki

Dept. of Earth, Atmospheric and Planetary Sciences

Massachusetts Institute of Technology

Cambridge MA 02139

$\mathrm{DOE} / \mathrm{ER} / 02534--\mathrm{Tl}$

DE86 000214

February, 1985

\section{DISCLAIMER}

This report was prepared as an account of work sponsored by an agency of the United States Government. Neither the United States Government nor any agency thereof, nor any of their employees, makes any warranty, express or implied, or assumes any legal liability or responsibility for the accuracy, completeness, or uselulness of any information, apparatus, product, or process disclosed, or represents that its use 'would not infringe privately owned rights. Reference herein to any specific commercial product, process, or service by trade name, trademark, manufacturer, or otherwise does not necessirily constitute or imply its endorsement, recommendation, or favoring by the United States Government or any agency thereof. The views and opinions of authors expressed herein do not necessarily state or reflect those of the United States Government or any agency the:reof.

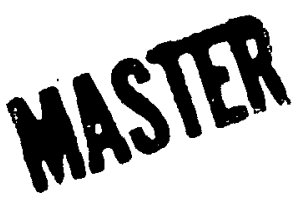




\section{DISCLAIMER}

This report was prepared as an account of work sponsored by an agency of the United States Government. Neither the United States Government nor any agency Thereof, nor any of their employees, makes any warranty, express or implied, or assumes any legal liability or responsibility for the accuracy, completeness, or usefulness of any information, apparatus, product, or process disclosed, or represents that its use would not infringe privately owned rights. Reference herein to any specific commercial product, process, or service by trade name, trademark, manufacturer, or otherwise does not necessarily constitute or imply its endorsement, recommendation, or favoring by the United States Government or any agency thereof. The views and opinions of authors expressed herein do not necessarily state or reflect those of the United States Government or any agency thereof. 


\section{DISCLAIMER}

Portions of this document may be illegible in electronic image products. Images are produced from the best available original document. 


\section{Introduction}

The present project has been titled "Seismological Investigation of Crack Formation in Hydraulic Rock Fracturing Experiments and in Natural Geothermal Environments". Recently it was renamed "CSIJP: The Seismology of Continental Thermal Regimes" in order to focus our research effort in line with the Continental Scientific Drilling Project.

We began our research in 1975 with the participation in two major geothermal projects, namely, the Hot Dry Rock Geothermal Energy Development Project of the Los Alamos National Laboratory and the Magma Tap Project of Sandia National Laboratories. The theory and methods developed for interpretation of various seismic experiments conducted at Fenton Hill, New Mexico and Kilauea Iki, Hawaii, however, found a variety of applications to other geothermal areas and volcanoes and our research has evolved into a new branch of seismology, called Geothermal Seismology or Volcanic Seismology. The list of publications in refereed journals and M.I.T. Ph.D. theses from the work supported by the present contract is shown in Table 1 and attests to this evolution. Our progress has also been described in ten annual reports to DOE, C00-2534-1 through C00-2534-10.

Our primary accomplishment has been the development of new seismological tools to define and characterize the geometry, mechanical construction and mass transport process of a geothermal system, and their application to various geothermal systems including the Fenton Hill Hot Dry Rock system, New Mexico, Kilauea and Kilauea Iki, Hawaij, Mt. St. Helens, Washington, and Long Valley, California.

The highly successful course of development of the present project is indicated by the publication of 26 papers (nnany of them are now standard references) in refereed journals, as well as by 3 Ph.D. theses by B. Chouet, J. Scheimer and M. Fehler who are now working along the line of their thesis 
research at U.S. Geological Survey, Lawrence Livermore National Laboratory and Los Alamos National Laboratory, respectively.

General approach

Our experience with the partially frozen lava lake, Kilauea Iki, described in Publication Nos. 3, 5, 8 and 1.6 in Table 1 taught us that a multiple use of conventional and unconventional methods is essential for exploring a complex geological body such as a geothermal system.

We found that the naturally occurring seismic events within Iki gave the most detailed information on the lateral extent of the magma reservoir. The dispersion of Love waves played an importarit role in defining the magma body because we could not use high-frequency bocly waves which suffered strong attenuation and scattering in the severely cracked crust. The SH waves from an earthquake outside Iki provided importart information on the physical properties of the magma body. All these results point out that the study of such a complex structure requires both active and passive seismic experiments using conventional and unconventional techriques.

To put this multiple approach on a sound scientific basis, our interpretation theory has been constructed on the basic assumption that a geothermal system can be modeled as "fluid-filled cracks".

Our multiple approach can be divided into two main areas: namely, the study of the source mechanism of seismic events in a geothermal system caused naturally or artificially by hydraulic fracturing, and the study of the structure and mechanical properties of the system using seismic signals generated naturally or artificially.

The coda method

One of our most original approaches to the study of source mechanism and structural properties using high frequency seismic waves is the development of 
the coda method. Publication no. 1 describes the method for analyzing coda waves to find the source, scattering and attenuation effects based on a random medium modeling. The method developed here was applied to Hawaii in no. 4, California in no. 7, Fenton Hill in no. 9, Japan in no. 12, and is currently being applied to Mt. St. Helens and Long Valley.

Among many important results from these applications, the most interesting discovery is about the difference in coda quality factor $Q_{C}$ between geothermal and non-geothermal areas. Fig. 1 shows a summary of $Q_{C}^{-1}$ for various regions as a function of frequency in the range from 0.01 to 100 $H z$. The $Q_{C}^{-1}$ value is low and weakly frequency dependent for tectonically stable areas, and is highly peaked for active areas. The $Q_{c}^{-1}$ curve for geothermal areas (Mammoth Lakes, Calif. and OTL station of Kilauea, Hawaii) shows a clear departure from other tectonically active areas. $Q_{C}^{-1}$ at geothermal areas is less frequency dependent and show higher values at high frequencies than other active areas. This can be explained if scattering by heterogeneity is the main cause of seismic attenuation in non-geothermal active areas, while absorption due to the presence of gas and magma become dominant at high frequencies in geothermal areas.

Recently, Castellano et al. (1984) measured $Q_{C}$ for seismic events in the Campi Flegrei Volcanic area, Italy and found that their values agree with the values obtained for kilauea. If this anomalous frequency dependence of $Q_{C}$ is unique to geothermal areas, we can use it as a simple reconnaissance tool for finding geothermal areas. 


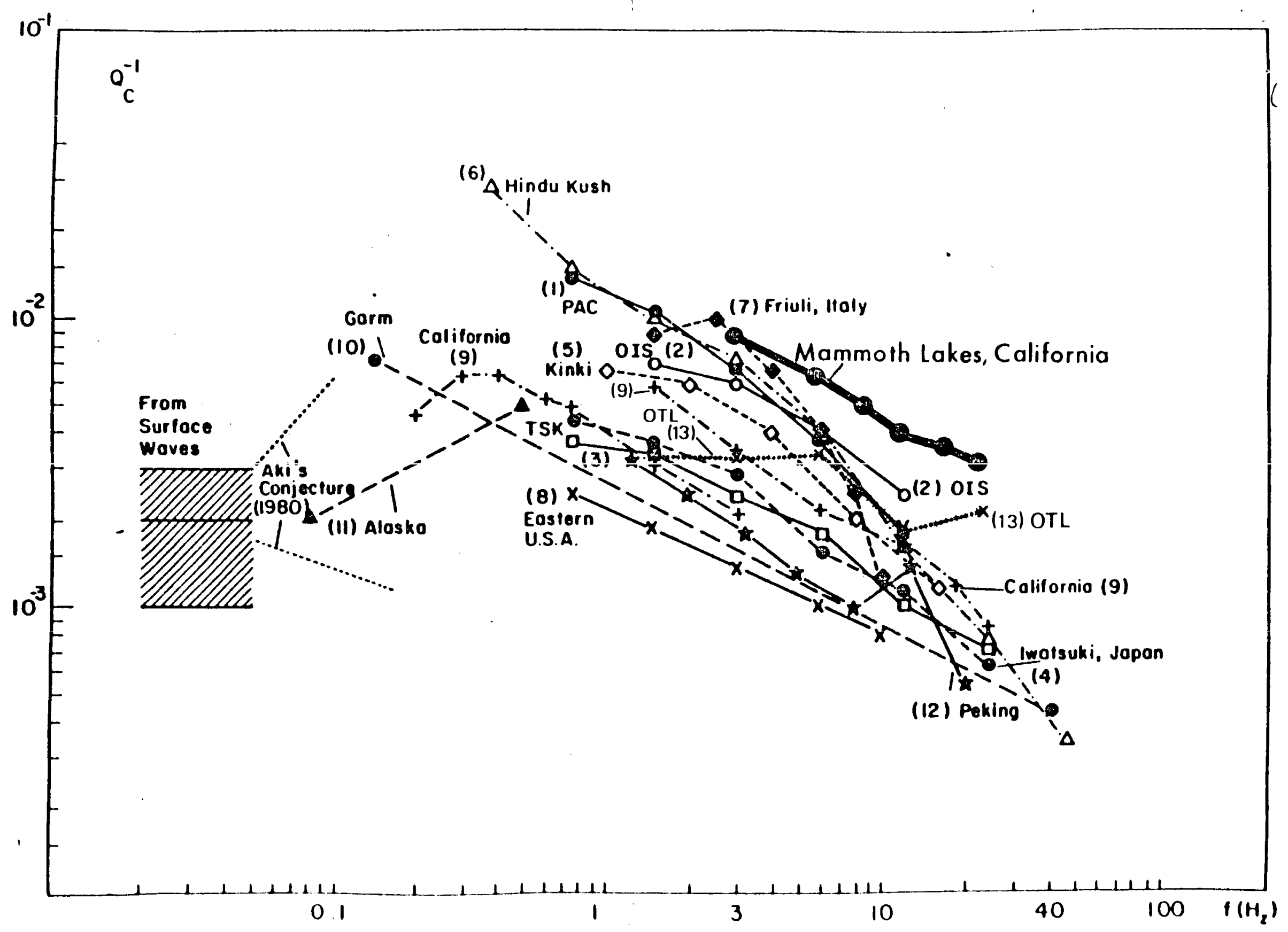

Fig. 1 The frequency dependence of $Q_{c}{ }^{-1}$ for various areas. 
Seismic Tomography

The deterministic approach to the structure study was also emphasized in our project. The so-called "3-D inversion" method (or more recently called "seismic tomography") developed by the principal investigator and his colleagues was applied to the data supplied from the U.S. Geological Survey and the results on major geothermal areas have been summarized and interpreted in terms of regional thermal regime in publication nos. 14,18 and 19 .

This method has been widely used around the world by many seismologists. Among many important results, the presence of distinct low velocity bodies under rhyolitic volcanoes in the western U.S. and its absence under andesitic volcanoes in Cascade Range are the most outstanding discovery as pointed out by Iyer (personal communication).

The resolution of seismic image has been sharpened by the use of local earthquake data, and Thurber (1984) was able to resolve a low velocity spot interpreted as the magma chamber in a generally high velocity zone of the Kilauea summit. Origin of volcanic tremors

Another major line of research has been the development of the seismic source model of volcanic tremor. We believe that the distinct character of the volcanic tremor is due to the involvement of fluid in seismic wave generation, and have developed a method for finding the geometry of the magma reservoir; its transport mechanism, and the physical properties of the magma such as in-situ viscosity, an important parameter for geothermal energy exploration. Publication no. 2 is our initial attempt to construct a model for volcanic tremor based on our basic assumption that a geothermal system is essentially a fluid-filled crack. We have improved upon the model through works published in nos. 15, 24, 27 and 29 . The method of interpretation thus 
developed has been applied to Kilauea, Hawaii (nos. 2, 13 and 15), and Mt. St. Helens (no. 21). We have estimated the rate of magma transport taking place under Hawai $i$ at the depth of $30 \sim 50 \mathrm{~km}$ during the past 20 years. We found that the transport rate at these depths is very stable, and is affected only slightly by the eruptive activity at the surface.

In order to quantify the tremor source, we have introduced an observable quantity called "reduced displacement", which is defined as

$\operatorname{R}\{\operatorname{RMS}(u)\}$ for body waves

and

$\sqrt{r \lambda} R\{R M S(u)\}$ for surface waves,

where $R$ is the hypocentral distance, $r$ is the epicentral distance, $\lambda$ is the wavelength and RMS $(u)$ is the root mean square displacement.

From the analysis of energetics, we can express the reduced displacement in terms of physical parameters of tremor source as

$$
\operatorname{R}\{\operatorname{RMS}(u)\}=\frac{1}{2 \pi} \quad \frac{1}{Q}\left(-\frac{1}{Q v}\right)^{1 / 2} \vee \frac{V}{2 f v p k}\{\operatorname{RMS}(\Delta P)\}
$$

for body waves, and

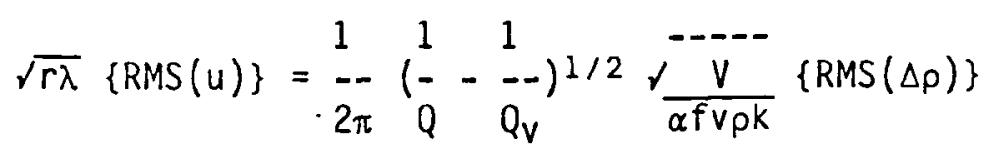

where $V$ is the volume of the magma body, $Q$ is the apparent quality factor of vibration of magma body, $Q v$ is the quality factor due to viscous damping in magma, $f$ is frequency of tremor, $v$ is wave velocity, $\rho$ is density, $k$ is the bulk modulus of magma, RMS $(\Delta \rho \mu$ is the root mean square pressure fluctuation in magma, and $\alpha$ is the ratio of the effective depth of penetration of surface wave to the wave length. The above equations relate the observable quantity with the physical parameters of tremor source. They show that the tremor amplitude is proportional to pressure fluctuation and the square root of magma volume. Publication no. 28 applies the above formulas to the Long Valley 
situation.

Publication no. 29 analyses detailed dynamics of the tremor source beyond the consideration of energetics by constructing a model consisting of a triggering mechanism, a resonator and a radiator.

The Fenton Hill Hot Dry Rock Geothermal System

The structure of the Fenton Hill Hot Dry Rock geothermal system has been a primary subject of our study. Publication no. 20 is a synthesis of all available data from active experiments. The main conclusion is that the Fenton Hill Hot Dry Rock reservoir is a highly complex fracture system consisting of major discrete vertical cracks intersected by several inclined joints which are surrounded by a large volume of rock containing small-scale cracks. Publication nos. 9, 17 , and 23 also describe the mechanical properties of the system revealed by various seismic experiments.

So far the most useful technique for determining the size and orientation of the hydrofractured crack is to map the seismic events induced by the pressurization. The principal investigator has been involved in the interpretation of their seismograms since the early experiments in mid-70's. From limited observations avaitable at early stages, he put forward a hypothesis that these seismic events are shear slip along pre-existing joints due to pre-existing tectonic stress caused by the decrease in normal effective stress due to the increase in pore pressure transmitted through aseismically opened tensile crack. This hypothesis was strongly supported by an extensive analysis of high quality data by various up-to-date methods carried out recently by the staff of Los Alamos National Laboratory and was presented at the Microseismic Anaysis Review Panel held at Los Alamos for 3 days in late June 1984. The principal investigator served as the panel chairman and a report is being prepared. The panel meeting was scientifically stimulating 
and productive and arrived at several reconmendations on the future research direction of the Hot Dry Rock project.

Data Collection by Digital Event Recorders

Throughout the course of our project, we have collected data from government agencies and university laboratories of various countries, including the U.S. Geological Survey, Los Alamos National Laboratory, Sandia National Laboratories, the California Division of Mines and Geology, the University of Kyoto, and the University of Paris. In addition to these data, we have constructed our own mobile network of nine digital event recorders and deployed them at Newberry Peak, Mt. St. Helens and Jamez Caldera. They have produced high-quality records which have led to several exciting discoveries. In particular, the one placed within the active crater of Mt. St. Helens recorded so-called "long-period events" and offered a clue to the solution of the origin of volcanic tremor.

Temporal Change of Coda $\underline{Q}$ Observed at the Crater Station of Mt. St. Helens

Furthermore, using the records obtained at the station in the active crater of Mt. St. Helens, we were able to cletect a change in the quality factor $Q$, by the coda wave method, before and after a small eruption. A similar change was observed at the Fenton Hill Hot Dry Rock site during a hydrofracturing experiment (Publication no. 9), and both can be attributed to the effects of pore pressure change. There are rapidly accumulating reports about coda $Q$ changes before volcanic eruption as well as earthquake occurrence. Chouet (Publication No.7) was first to observe such a temporal change in central California. The monitoring of coda $Q$ is desired for predicting possible eruptions in Long Valley, California and Campi Flegrei, Italy, where the magmatic activity is currently suspected. 
References

Castellano, M., E. Del Pezzo, G. DeNatale and A. Zollo, Seismic coda Q and turbidity coefficient at Campi Flegrei Volcanic area: preliminary results, submitted to Bulletine Volcanologique, 1984.

Thurber, C.H., Seismic detection of the summit magma complex of Kilauea volcano, Hawaii, Science, 223, 1984. 
List of Publications in Refereed Journals and Ph.D. Theses

Supported by the Contract

1. Chouet, B., Source, scattering and attenuation effects on high frequency seismic waves, Ph.D. thesis, Massachusetts Institute of Technology, 183 pp., 1976.

2. Aki, K., M. Fehler, and S. Das, Source mechanism of volcanic tremors: Fluid driven crack models and their applicationto the 1963 Kilauea eruption, J. Volcan. Geotherm. Res., 2, 259-287, 1977.

3. Aki, K., B. Chouet, M. Fehler, G. Zandt, R. Koyanagi, J. Colp, and R.G. Hay, Seismic properties of a shallow maglma reservoir in Kilauea Iki by active and passive experiments, J. Geophys. Res., 83, 2273-2282, 1978.

4. Chouet, B., K. Aki, and M. Tsujiura, Regional variation of the scaling law of earthquake source spectra, Bull. Seis. Soc. Am., 68, 49-79, 1978.

5. Fehler, M., and K. Aki, Numerical study of diffraction of plane elastic waves by a finite crack with application to location of a magma lens, Bull. Seis. Soc. Am., 68, 573-598, 1978.

6. Scheimer, J.F., Experimental study of seismic scattering by a pennyshaped crack, Ph.D. thesis, Dept. of Earth and Planetary Sciences, M.I.T., 1978.

7. Chouet, B., Temporal variation in attenuation of earthquake coda near Stone Canyon, California, Geophys. Res. Letters, 6, 143-146, 1979.

8. Chouet, B., Sources of seismic events in the cooling lava lake of Kilauea Iki, Hawai i, J. Geophys. Res., 84, 2315-2330, 1979. 
9. Fehler, M., Seismological investigation of the mechanical properties of a hot dry rock geothermal system, Ph.D. thesis, Dept. of Earth and Planetary Sciences, M.I.T., 1979.

10. Aki, K., Attenuation of shear-waves in the lithosphere for frequencies from 0.05 to $25 \mathrm{~Hz}$, Phys. Earth Planet. Int., 21, 50-60, 1980.

11. Bouchon, M., Calculation of complete seismograms for an explosive source in a layered medium, Geophysics, 45, 197--203, 1980.

12. Aki, K., Source and scattering effects on the spectra of small local earthquakes, Bul1. Seis. Soc. Am., 71, 16i87-1700, 1981.

13. Aki, K., and R. Koyanagi, Deep volcanic tremor and magma ascent mechanism under Kilauea, Hawaii, J. Geophys. Res., 86, 7095-7109, 1981.

14. AKi, K., 3-D inhomogeneities in the upper mantle, Tectonophysics, 75 , $31-40,1981$.

15. Chouet, B., Ground motion in the near field of a fluid-driven crack and its interpretation in the study of shallow volcanic tremor, J. Geophys. Res., 86, 5985-6016, 1981.

16. Chouet, B., and K. Aki, Seismic structure and seismicity of the cooling lava lake of Kilauea Iki, Hawaij, J. Volcanol. Geotherm. Res., 9, 41-56, 1981.

17. Fehler, M., Changes in $P$ waves velocity during operation of a hot dry rock geothermal system, J. Geophys. Res., 86, 2925-2928, 1981.

18. Zandt, G., Seismic images of the deep structure of the San Andreas fault system, central coast ranges, California, J. Geophys. Res., 86, 5039-5052, 1981.

19. Aki, K., Three-dimensional seismic inhomogeneities in the lithosphere and asthenosphere: Evidence for decoupling in the lithosphere and flow in the asthenosphere, Rev. Geophys. Space Physics, 20, 161-170, 1982. 
20. Aki, K., M. Fehler, R.L. Aamodt, J.N. Albright, R.M. Potter, C.M. Pearson, and J.W. Tester, Interpretation of seismic data from hydraulic fracturing experiments at the Fenton Hill, New Mexico, hot dry rock geothermal site, J. Geophys. Res., 87, 936-944, 1982.

21. Fehler, M., and B. Chouet, Operation of a digital seismic network on Mount St. Helens volcano and observations of long period seismic events that originate under the volcano, Geophys. Res. Letters, 9, 1017-1020, 1982.

22. Fehler, M., Interaction of seismic waves with a viscous liquid layer, Bull. Seis. Soc. Am., 72, 55-72, 1982.

23. Fehler, M., Using dual-well seismic measurement to infer the mechanical properties of a hot dry rock geothermal system, J. Geophys. Res., 87, $5485-5494,1982$.

24. Chouet, B., Free surface displacements in the near field of a tensile crack expanding in three dimensions, J. Geophys. Res., 87, 3868-3872, 1982.

25. Wu, R.S., Attenuation of short period seismic waves due to scattering, Geophys. Res. Letters, 9, 9-12, 1982.

26. Wu, R.S., Mean field attenuation and amplitude attenuation due to wave scattering, Wave Motion, $\underline{4}, 305-316,1982$.

27. Chouet, B., Ground motion near an expanding preexisting crack, J. Volcanol. Geotherm. Res., 19, 367-379, 1983.

28. Aki, K., Evidence for magma intrusion during the Mammoth Lakes earthquakes of May, 1980 and implications of the absence of volcanic (harmonic) tremor, J. Geophys. Res., in press. See Progress Report C00-2534-10. 29. Chouet, B., Ground response generated by the magmatic excitation of a buried volcanic pipe, a source model for shallow long-period volcanic events and harmonic tremor, Progress Report C00-2534-9. 